\title{
Aplikace intervenčního programu hudebně-pohybové výchovy do hodin školní tělesné výchovy na ZŠ
}

\section{Application of the new interventional musical-movement program into the physical education lessons in secondary schools}

\author{
Kateřina Doležalová, Viléma Novotná \\ Fakulta tělesné výchovy a sportu Univerzity Karlovy v Praze
}

\begin{abstract}
Abstrakt
Cílem přispěvku je prezentovat obsah a výsledky předvýzkumného šetření disertační práce. Využití hudebně-pohybové výchovy (HPV), která je součástí rámcově vzdělávacích programů základních škol, je ve školní praxi nedostačující. Přičinami jsou nedostatečná príprava budoucích učitelů, málo atraktivní tradiční způsob výuky a malá nabídka moderní metodické podpory pro učitele. Proto je cílem disertační práce vytvořit nový intervenční program HPV a ověrit jeho působení na úroveň vybraných hudebně-pohybových schopností. Príspěvek prezentuje hlavní charakteristiky intervenčního programu HPV a výsledky získané v rámci předvýzkumného ověřování programu na základní škole. Měření účinnosti hudebně pohybového programu bylo realizováno prostřednictvím testů hudebně-pohybových schopností. Hodnocení aktuální úrovně hudebnè-pohybových schopností bylo realizováno dvakrát tj. před a po ukončení intervence. Na základě výsledků testu normality distribuce dat byly použity parametrické i neparametrické statistické testy. Experimentální soubor byl složen ze 14 studentek 2. stupně základní školy v Praze. U testů posuzujících úroveň rytmické percepce a rytmické přizpůsobivosti byly rozdíly mezi pretestem a posttestem nevýznamné. Oproti tomu u testu dynamické rovnováhy a společné pohybové tvorivosti byly rozdily statisticky významné. Výsledky mohly být ovlivněny malým počtem respondentek. Předpokládáme, že výzkum vybraných aspektů v oblasti výuky hudebně-pohybové výchovy prispěje k získání dalších poznatků, které mohou pomoci k vytváření nových hudebně-pohybových programů a jejich implementaci do hodin školní tělesné výchovy.
\end{abstract}

\begin{abstract}
The aim of this paper is to present the content and results of pre research study of dissertation. Musicalmovement education is part of the curriculum of physical education lesson. Although the educational content of physical education remains essentially the same during the year, the methods and forms of teaching are more subjected on the social requirements. Existing musical-movement education is using traditional forms of teaching, which is not that attractive for students. Therefore, the aim of the study is to create the new interventional musical-movement program and verification of its effect on the level of the selected music and movement skills. The paper presents the main characteristics of the intervention program and results obtained within the pre research in secondary school.

Measuring the effectiveness of the musical-movement program was implemented through tests of music-movement abilities in the group of 14 girls, students of secondary school in Prague. The tests assessing the level of rhythmic perception and rhythmic adaptability, shows no statistically significant differences in the pretest and posttest. The tests of dynamic balance and collective movement creativity demonstrate statistically significant effect. The results could be influenced by a small number of respondents. We assume, the results of music movement education will contribute to the further insights that can contribute to creating new musica- movement programs and help them with implementation in to the physical education lessons.
\end{abstract}


Klíčová slova: výuka, rámcově vzdělávací program, tělesná výchova, hudebně-pohybové schopnosti, kreativita

Keywords: education, curriculum, physical education, music and movement skills, creativity

Př́spěvek vznikl v rámci řešení projektu PROGRES 41 na UK FTVS.

\section{ÚVOD}

Škola je nedílnou součástí rozvoje mladého jedince. Školní prostř̌edí, učitelé, kolektiv studentů i výchovné a vzdělávací podněty by měly harmonicky působit na celou osobnost studenta. Výchovně vzdělávací proces ve škole je frekventovaným tématem a stává se předmětem diskuzí široké veřejnosti. A to zejména $\mathrm{v}$ otázkách týkajících se metod učení, obsahu a jeho vymezení, způsobu zprostředkování učiva a možnosti ověřování kompetencí.

Obecně je známo, že ve školní výuce převažuje kognitivní, receptivní a logické myšlení, což v žákovi může potlačovat kreativní inteligenci a tvůrčí jednání (Pastorová, 2010). Stále je častým způsobem výuky teoretických i praktických předmětů tzv. frontální způsob výuky. Ve vztahu k aktivitě žáka, jeho podílení se na tvorbě obsahu, realizaci a hodnocení je tento způsob výuky považován za nevhodný. Žák se stává pouze pozorovatelem a pasivním účastníkem výchovně vzdělávacího procesu. Dochází k převaze receptivních činností, při kterých si žák pouze osvojuje nové poznatky. Je třeba zapojit do výuky více kreativních činností, při kterých se žák stává aktivním článkem a podílí se na vedoucí roli ve výchovně vzdělávacím procesu. (Maňák, 2011). Na druhou stranu, při osvojování poznatků, kde mají hlavní roli kognitivní procesy a cílem je osvojení si maximálního rozsahu informací, má frontální výuka své opodstatnění (Švec \& Maňák, 2003).

Ve školní tělesné výchově je tanec specifickou činností, jež pozitivně ovlivňuje kultivované vystupování, estetický pohyb, tvưrčí jednání, emocionální prožitek a podněcuje kreativitu. Proto se tanec připojil k dalším pohybovým aktivitám, které pomáhají naplňovat vzdělávací cíle ve školním prostředí (Nanu, 2010). Rámcově vzdělávací program (RVP) přímo uvádí, že tanečně-pohybová výchova jako doplňující vzdělávací obor vytváří další prostor pro utváření a rozvíjení klíčových kompetencí, zejména kompetencí sociálních a personálních, komunikativních a občanských. Zároveň přispívá k dosahování cílů základního vzdělávání (VƯP, 2013).

V České republice je cvičení s hudbou a rytmická gymnastika učebním obsahem rámcově vzdělávacích programů. Implementace, plánování a realizace pohybového obsahu rytmické gymnastiky a tance je považováno za problematické (Chrudimský \& Novotná, 2009). Pokorná a Jansa (2012) ve výsledcích svého výzkumu uvádějí, že až jedna třetina škol nevyužívá ve svých vzdělávacích programech cvičení s hudbou a jedna polovina taneční průpravu. Hudebně-pohybová a taneční výchova je málo využívána proto, že pedagogové nejsou dostatečně na tuto náročnou výuku připraveni a současně nemají vhodné moderní metodické materiály pro výuku (Brtníková, 2008). Často je možno se setkat s praxí, že učitelé při výuce programů cvičení s hudbou používají zastaralé taneční formy a styly, které nejsou pro žáky zajímavé. Tím obliba rytmické gymnastiky a tanců u studentů značně klesá (Frömel \& kol. 2002).

Z dlouhodobé studie hodnotící oblíbenost obsahu školní tělesné výchovy u dívek mezi 13 a 17 lety (Sigmund, Frömel, Chmelík, Lokvencová \& Groffik, 2009) vyplynulo, že hudebně-pohybové činnosti působí pozitivně na motivaci dívek ke sportovním aktivitám. Hodiny školní tělesné výchovy s obsahem aktivit spojených s hudbou mohou výrazně přispět $\mathrm{k}$ formování pozitivního postoje k pohybové aktivitě na základní škole.

Tvorba, implementace a výuka hudebně-pohybové výchovy na úrovni základního vzdělávání má svá opodstatnění. Tanec a hudebně-pohybová výchova jsou formy pohybové aktivity posky- 
tující tělesné a psychické benefity, jako je pohyblivost, aerobní vytrvalost, zvýšené sebevědomí a pohybová motivace (Battisti \& Haibach, 2011). Pokud je tanec zařazen do vzdělávacího procesu v rámci tělesné výchovy, je možno rozvinout u studentek kritické myšlení, kooperaci a týmovou spolupráci. Je podporováno jejich sebevyjádření, kulturní povědomí a emocionální komunikace (Millar, 2011). Na plnění těchto úkolů musí být učitelé nejen připraveni, ale musí mít pro náročnou výuku hudebně-pohybové výchovy i odpovídající podmínky. Z posouzení rozsahu hodin výuky věnovaných přípravě učitelů na fakultách připravujících učitele je možno konstatovat, že počet hodin je nedostačující a výuka není zajištěna potřebnými oporami.

Inovace způsobu výuky hudebně-pohybové výchovy na základní škole se stala předmětem disertační práce. K témuž účelu byl vytvořen intervenční program hudebně-pohybové výchovy. K ověření účinnosti navrženého programu byl proveden předvýzkum, který byl zmenšeným modelem hlavního výzkumu ve všech jeho fázích (Chráska, 2016). Cílem výzkumu bylo vytvoření inovativního způsobu výuky hudebně-pohybové výchovy a ověření jeho vlivu na úroveň vybraných hudebně-pohybových dovedností prostřednictvím testů.

Byly stanoveny následující hypotézy:

H0: Intervenční program nemá vliv na rozvoj vybraných hudebně-pohybových dovedností.

H1: Intervenční program má vliv na rozvoj vybraných hudebně-pohybových dovedností.

\section{METODIKA}

Byl ověřován vliv šestitýdenního intervenčního programu s obsahem hudebně-pohybové výchovy na změny v úrovni hudebně-pohybových schopností, prezentovaných určitými dovednostmi. Předvýzkumu se zúčastnily studentky základní školy Sázavská na pražských Vinohradech. Soubor tvořilo 14 žákyň ve věku 12-14 let, pro které je podle rámcově vzdělávacích plánů základních škol určena hudebně-pohybová výchova. Vzhledem k záměrnému výběru dívek do skupin (školní třídy) měl plán výzkumu podobu kvaziexperimentu. Ze dvou tříd 7. a 8. ročníku ZŠ byla učitelkou tělesné výchovy vybrána jedna experimentální skupina, která byla hodnocena pretestem a posttestem vybraných hudebně-pohybových testů (Brtníková 2008, Frömel et al., 2000, in Brtníková, 2008). Mezi pretestem a posttestem absolvovaly studentky po dobu šesti týdnů celkem deset lekcí intervenčního programu s inovačními prvky hudebně-pohybové výchovy. Program HPV probíhal pod vedením autorky programu s participací vyučující učitelky v rámci hodin školní tělesné výchovy. $\mathrm{Z}$ důvodu omezených podmínek poskytovaných školou nebylo možno pro tento výzkum zajistit kontrolní skupinu.

Na základě studia výzkumných prací české i zahraniční literatury byly zvoleny aplikované testy použité Brtníkovou (2008). Testy hudebně-pohybové: 1. test rytmické percepce a 2. test rytmické přizpůsobivosti; test motorický: 3. test dynamické rovnováhy; test pohybové tvorivosti: 4 . test společné pohybové tvořivosti. Zjištění působnosti programu bylo ověřeno komparativním experimentem s párovými testy (pretest a posttest). Testy byly zvoleny tak, aby byly dobře proveditelné ve školním prostředí ve skupině studentek. Důraz byl kladen na obsahovou validitu testu a vhodnou délku testu vzhledem k realizaci během vyučovací jednotky. Testy byly hodnoceny dvěma expertkami a učitelkou tělesné výchovy. Pro ilustraci jsou uvedeny popisy jednotlivých testů a jejich hodnocení:

Test rytmické percepce hodnotí počet správných tlesknutí na druhou a třetí dobu čtyřdobého rytmu. Hodnotí se každý správný dvojúder (správné tlesknutí na druhou i třetí dobu), ohodnocen je jedním bodem. Maximální počet získaných bodů je 14, minimální počet získaných bodů je 0 .

Test rytmické prrizpi̊sobivosti testuje dobu přizpůsobení pohybu do rytmu. Testovaný stř́idá dvě tlesknutí a dvě dupnutí postupně oběma nohama (pořadí nohou si určí měřená osoba) na každou dobu čtyřdobého rytmu hudební nahrávky. Měří se doba, kterou měřená osoba potřebuje ke zko- 
ordinování svých pohybů s rytmem hudební předlohy. Pokud měřená osoba po celou dobu trvání hudební nahrávky své pohyby s hudbou nezkoordinuje, její výsledek je $28 \mathrm{~s}$. Jakmile testovaný poprvé správně přizpůsobí své pohyby rytmu hudby, zastaví se čas. Jestliže následně dojde opět ke změně rytmu pohybu v nesouladu s rytmem hudby, čas se opět začíná měřit a přičía se k úvodnímu času.

Test dynamické rovnováhy měří čas, za který testovaný překoná zadanou vzdálenost $6 \mathrm{~m}$ tandemovou chůzí. Testovaný provádí chůzi po čáře, a to tak, že pata přední nohy se musí dotýkat špičky zadní nohy. Č́ru tvoří $6 \mathrm{~m}$ dlouhý provázek přilepený na zemi. Testované osoby provádí test bez obuvi. Počíá se každý neúspěšný krok. Pokud se pata přední nohy nedotkne špičky nohy zadní, krok se považuje za neúspěšný. Rovněž pokud se celé chodidlo dostane mimo čáru, krok je počítán jako neúspěšný. Na závěr se k naměřenému času přičtou 3 sekundy za každý neúspěšný krok.

Test společné pohybové tvořivosti probíhá tak, že jsou měřené osoby rozděleny do menších skupin (maximálně 10 osob ve skupině). V̌̌echny skupiny vytvářejí ve stejný čas pohybovou kompozici na zadanou hudební nahrávku o délce 40 sekund. Každá skupina se podílí pouze na vlastní pohybové kompozici. Čas na přípravu a tvorbu hudebně-pohybové kompozice je předem stanoven (v našem př́padě 25 minut). Výsledek společné pohybové tvořivosti zaznamenané na videozáznamu je vyhodnocen dle kritérií hodnocení hudebně-pohybové kompozice známkou na škále 0 až 10 bodů. Hodnocení provádějí samostatně tři hodnotitelé. Výsledné hodnocení je aritmetickým průměrem známek všech hodnotitelů.

\section{OBSAH INTERVENČNÍHO PROGRAMU HUDEBNĚ-POHYBOVÉ VÝCHOVY}

Obsahem hudebně-pohybového programu byl nácvik dovedností, jejichž realizace vyžadovala uplatnění vybraných hudebně-pohybových schopností. Cvičení pro rozvoj hudebně-pohybových schopností a nácvik hudebně-pohybových dovedností bylo rozděleno do pěti skupin: cvičení pro rozvoj sluchové percepce; cvičení na rozvoj přizpůsobení se pohybu a rytmu; cvičení na zdokonalení techniky cvičení bez náčiní; cvičení pro rozvoj kreativity; nespecifická cvičení pro rozvoj hudebně-pohybových schopností.

Cvičení pro rozvoj sluchové percepce: poznávání písní podle melodie; zapamatování si rytmu a následné vytleskání; tleskání, dupání, luskání do rytmu - na libovolnou dobu nebo doby v ryt$\mathrm{mu}$; hledání první, druhé, třetí doby v rytmu; provádění jednoduchých cvičení v daném rytmu, s využitím např. chůze, běhu, poskoků a obratů.

Cvičení na rozvoj přizpůsobení pohybu a rytmu: chůze v souladu s rytmickou předlohou; nácvik frázování - rytmický model za použití hry na tělo; skákání přes švihadlo s rytmickou předlohou; individuální improvizace - studentky vytváří rytmický model; nácvik připravené pohybové skladby.

Cvičení na zdokonalení techniky cvičení bez náčiní: rozcvičení s hudebním doprovodem; taneční sestavy na studentkami preferovanou hudbu s prvky zumby, hiphopu, latinsko-amerických tanců; nácvik tanečních kroků: chacha, waltz, samba, country tanec.

Cvičení na rozvoj kreativity obsahuje nap̌r. cvičení: „STOP“. Studentky běhají na hudbu libovolně po prostoru. Po vypnutí hudby „stop“ ustrnou ve svém pohybu. „VZTAH“. Účastnice stojí za sebou v kruhu a předávají si navzájem pohyb, který předvede první. Každá kopíruje pohyb cvičenky před sebou. „ZRCADLO“. Ve dvojicích proti sobě studentky napodobují zrcadlově pohyby své partnerky, nebo provádějí opačně pohyby v prostoru. „OVLÁDÁNÍ TĚLA“. Na hudební doprovod jedna ze studentek navrhne pohybový motiv střídání chůze s nehybností, např́iklad chůze, chůze, klid, klid. Postupně si každá určí vlastní pohybový motiv stř̌idání nehybnosti s chůzí.

Nespecifická cvičení pro rozvoj hudebně-pohybových schopností: kruhový trénink s hudebním doprovodem; sestava posilovacích cviků s hudebním doprovodem; power jóga s hudebním dopro- 
vodem; instruktážní masáž ve dvojicích s tenisovými míčky na relaxační hudbu; nácvik a realizace vlastní pohybové skladby vytvořené ve skupině.

\section{POSTUP VÝZKUMU A STATISTICKÁ ANALÝZA}

V předvýzkumné studii byl oveř̌ován vliv intervenčního programu aplikovaný v hodinách školní tělesné výchovy na Z Ž v délce trvání 6 týdnů. Byl sestaven plán lekcí, které byly postupně realizovány v hlavní části vyučovací jednotky. Doba trvání každé intervence byla 20 minut.

\section{Statistická analýza}

Deskriptivní statistika byla použita pro popis základní charakteristiky výzkumného souboru. U všech výsledků vstupních a výstupních vybraných testů hudebně-pohybových schopností bylo testováno normální rozdělení dat prostřednictvím Shapiro-Wilkova testu s určenou hladinou statistické významnosti $\alpha=0,05$.a provedena grafická analýza distribuce testových skórů prostřednictvím krabicových grafů. Na základě výsledků byl proveden výběr statistických testů pro ověření rozdílů pretestu a posttestu vybraných testů hudebně-pohybových schopností. Párový t-test pro data s normálním rozdělením a neparametrický Wilcoxonův test pro data s distribucí jinou. Všechny statistické testy byly realizovány s $5 \%$ rizikem $(\alpha=0,05)$. Statistická analýza byla provedena $\mathrm{v}$ programu STATISTICA.

\section{VÝSLEDKY}

Čtrnáct žákyň základní školy druhého stupně ve věku od 12 do 14 let absolvovalo šestitýdenní intervenční pohybový program zaměřený na stimulaci hudebně-pohybových schopností. Výsledky Shapiro-Wilkova testu ukazují, že testové skóre pretestu i posttestu dynamické rovnováhy a společné pohybové tvořivosti vykazují normální distribuci dat (viz tab. 1). Rozdělení dat u testů rytmické percepce a rytmické přizpůsobivosti naopak normální distribuci nevykazuje.

Tab. 1: Výsledky Shapiro-Wilkova testu

\begin{tabular}{|l|l|c|c|}
\hline & Proměnná & SW-W & p-hodnoty \\
\hline Pretest & Rytmická percepce & 0,6526 & 0,0001 \\
\hline Posttest & Rytmická percepce & 0,7743 & 0,0024 \\
\hline Pretest & Rytmická přizpůsobivost & 0,7738 & 0,0024 \\
\hline Posttest & Rytmická přizpůsobivost & 0,6670 & 0,0002 \\
\hline Pretest & Dynamická rovnováha & 0,9430 & 0,4578 \\
\hline Posttest & Dynamická rovnováha & 0,9445 & 0,4789 \\
\hline Pretest & Společná pohybová tvořivost & 0,9303 & 0,3078 \\
\hline Posttes & Společná pohybová tv. & 0,9135 & 0,1772 \\
\hline
\end{tabular}

Výsledky Shapiro-Wilkova testu normality jsou zřejmé v grafech 1-4, kde je patrné rozdělení souboru dat u všech realizovaných testů obou měření. Ani v jednom z př́ípadů se neobjevují extrémní ani odlehlé hodnoty. Mediány všech získaných souborů měření ukazují na změny stř̌edních hodnot sledovaného souboru u všech testů s patrnou tendencí zlepšení úrovně hudebně-pohybových schopností. 


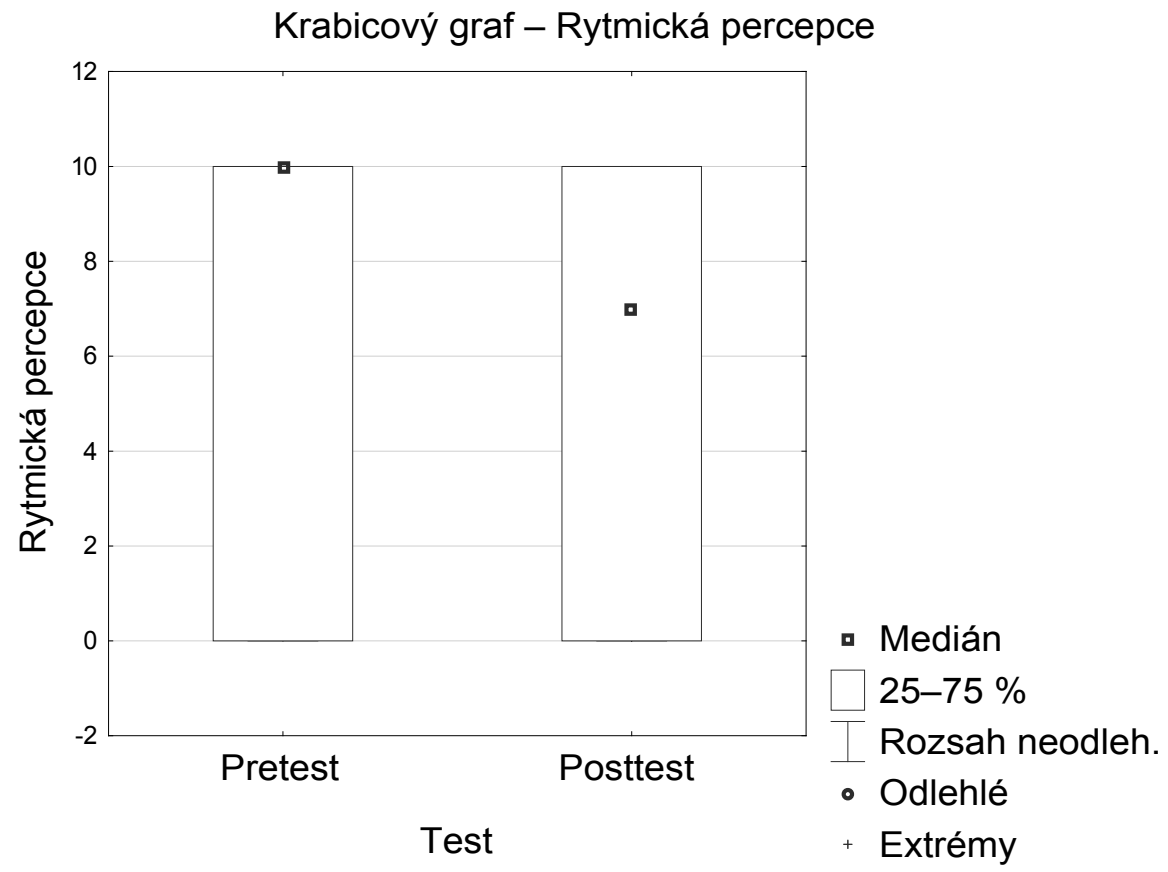

Obr. 1: Distribuce testových skorů v testu Rytmické percepce

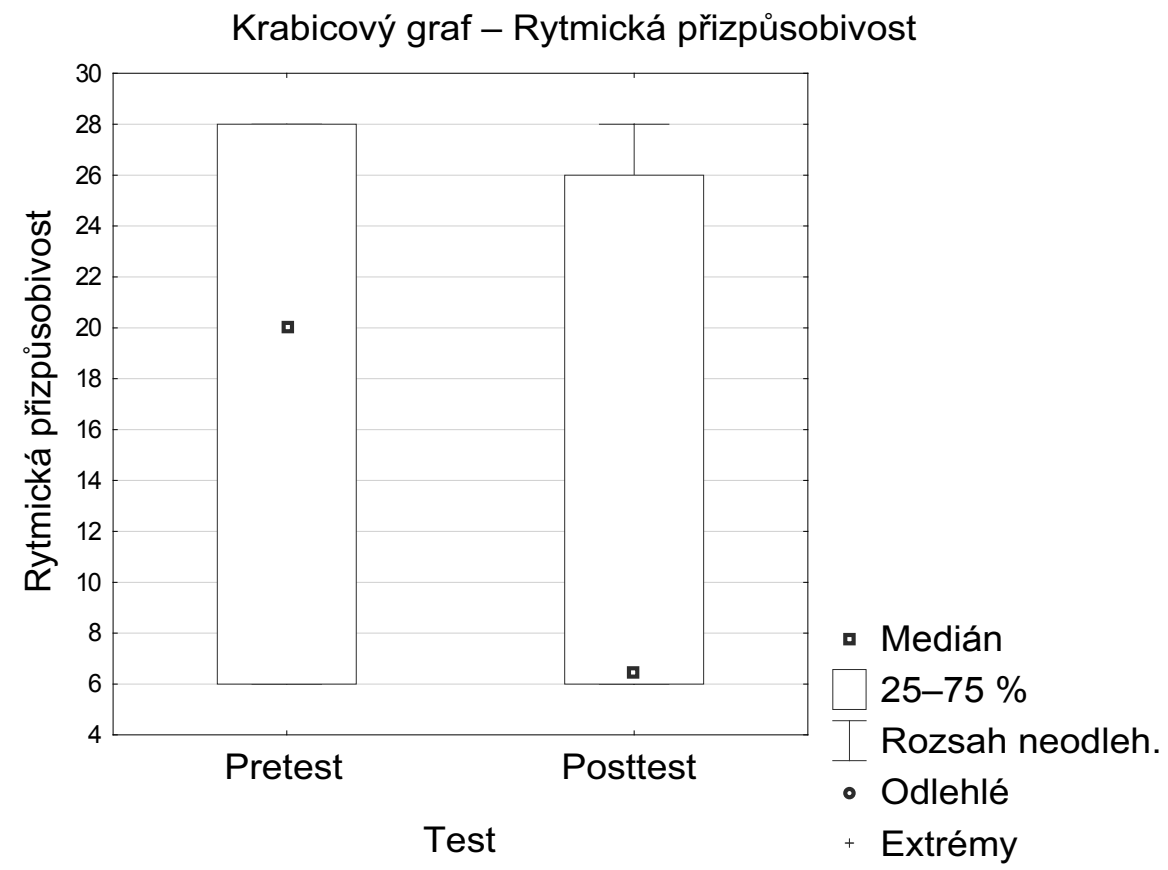

Obr. 2: Distribuce testových skorů v testu Rytmické přizpůsobivosti 


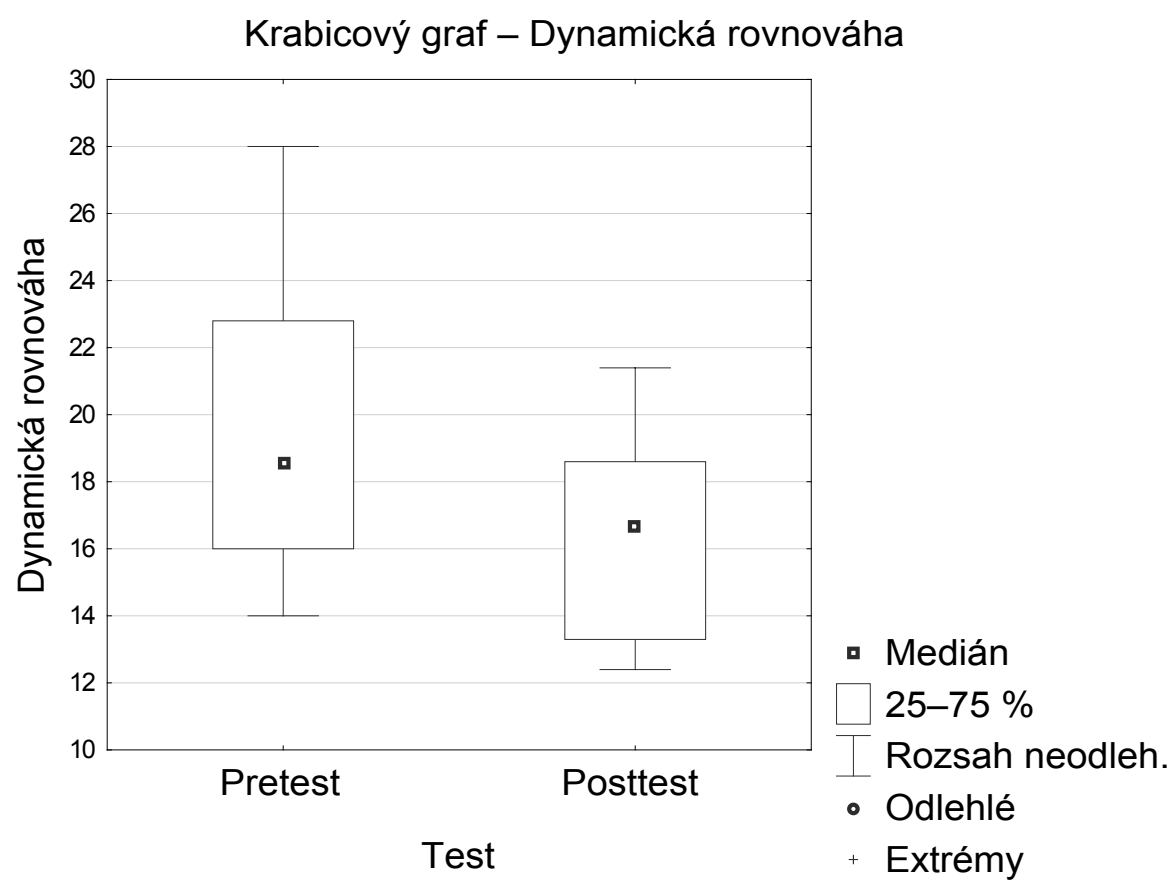

Obr. 3: Distribuce testových skorů v pretestu a posttestu Dynamické rovnováhy

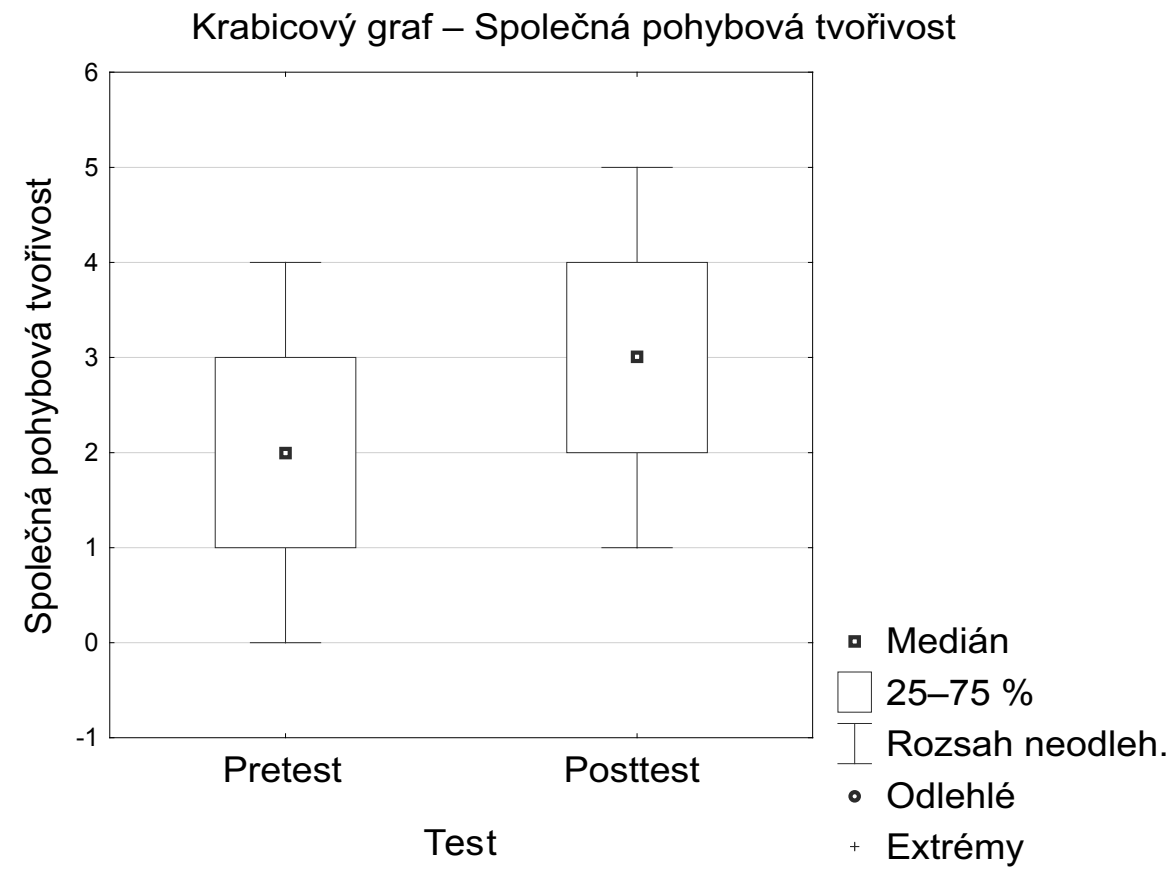

Obr. 4: Distribuce testových skorů v pretestu a posttestu Společné pohybové tvořivosti 
Tab. 2: Výsledky Rytmické percepce a R. přizpůsobivosti: Wilcoxonův párový test

\begin{tabular}{|l|c|c|c|}
\hline Proměnná & Průměr & Směrodatná odchylka & p-hodnoty \\
\hline Rytmická percepce - pretest & 5,79 & 4,87 & \\
\hline Rytmická percepce - posttets & 5,36 & 4,37 & 0,554 \\
\hline Rytmická přizpůsobivost - pretest & 17,29 & 9,7 & \\
\hline Rytmická přizpůsobivost - posttest & 13,71 & 9,95 & 0,441 \\
\hline
\end{tabular}

Výsledky jsou platné na hladině významnosti 0,05

Získané výsledky testů rytmické percepce a rytmické přizpůsobivosti neprokázaly statisticky významné zlepšení (Tabulka č. 2). P-hodnoty testů jsou totiž vyšší než zvolená hladina významnosti.

Tab. 3: Výsledky dynamické rovnováhy a společné pohybové tvořivosti:T-test

\begin{tabular}{|l|c|c|c|}
\hline Proměnná & Průměr & Směrodatná odchylka & p-hodnoty \\
\hline Dynamická rovnováha - pretest & 19,407 & 4,263 & \\
\hline Dynamická rovnováha - posttest & 16,386 & 2,785 & 0,003 \\
\hline Společná pohybová tvořivost - pretest & 2,071 & 1,207 & \\
\hline Společná pohybová tvořivost - posttest & 2,867 & 1,406 & 0,001 \\
\hline
\end{tabular}

Výsledky jsou platné na hladině významnosti 0,05

U testu dynamické rovnováhy a společné pohybové tvořivosti byl prokázán statisticky významný rozdíl $\mathrm{v}$ hodnotách pretestu a posttestu. P-hodnota t-testu dynamické rovnováhy byla totiž nižší $(0,003)$ než zvolená hladina významnosti $(0,05)$. P-hodnota t-testu společné pohybové tvořivosti byla také nižší $(0,001)$ než stejně zvolená hladina významnosti. Výsledky párového t-testu byly provedeny u dvou ze čtyř testů. Konkrétně u testů dynamické rovnováhy a společné pohybové tvořivosti. $\mathrm{V}$ obou případech výsledky ukázaly na statisticky významné rozdíly mezi pretestem a posttestem (viz tabulka 3 ).

\section{DISKUSE}

Realizovaný intervenční program a analýza dosažených výsledků přinesly dvě rozdílná zjištění. Na straně jedné signifikantní rozdíly ve výsledcích testovaných žákyň v testu dynamické rovnováhy a v testu společné pohybové tvořivosti. Na straně druhé nevýznamné změny v testech rytmické percepce a rytmické přizpůsobivosti. Vzhledem ke krátké době intervence nepředpokládáme, že by další volnočasové aktivity nebo přirozený senzitivní rozvoj dívek mohl významně ovlivnit výsledky specifických testů.

Vliv aplikovaného intervenčního programu hudebně-pohybové výchovy na úroveň dynamické rovnováhy sledovaného souboru si vysvětlujeme podstatou testu, který je testem motorickým. Předpokládáme, že zvýšení úrovně tělesné zdatnosti v důsledku pohybové aktivity může vést i ke zlepšení dynamické rovnováhy. Podle Měkoty a Novosada (2005) je úroveň dynamické rovnováhy závislá na úrovni vestibulárního aparátu, vizuální kontrole, psychickém stavu a biomechanickém momentu. Pohybovým obsahem rytmické gymnastiky, cvičení hudebně-pohybové výchovy i tance, jsou právě takové pohybové aktivity estetického charakteru, které jsou zaměřeny na kvalitu a přesnost provedení. Při vlastní realizaci jsou kladeny, a tudíž i stimulovány funkce gnostické, které se rovněž podílejí na udržování rovnováhy. Pozitivní vliv tanečního sportu na úroveň koordinačních schopností (statické a dynamické rovnováhy, rytmické percepce a motorické docility) 
publikuje Honková (2011). Brtníková (2008) dokládá výrazný vliv pohybových mimoškolních tanečních aktivit na úroveň dynamické rovnováhy. V neposlední řadě Pastorová (2010) uvádí, že tanec a pohybová výchova poskytují úměrnou pohybovou zátěž, která udržuje pohybový systém v přirozené funkci i struktuře, a výkon se postupně zlepšuje podle dávkování zátěže. Obohacují se pohybové projevy a zlepšuje se schopnost spojovat intelektuální a citové podněty s fyzickými.

Realizovaný intervenční program modernizované hudebně-pohybové výchovy prokázal u skupiny respondentek pozitivní efekt v oblasti společné pohybové tvořivosti. Při vlastní tvorbě nebyl posuzován př́nos jednotlivkyň pro vytvořenou kompozici, ale byl hodnocen společný výsledek. Při předvedení pohybové skladby neprojevovaly žákyně viditelnou obavu z vystoupení. Pokorný (1996) uvádí jako prvky tvořivého myšlení: nápaditost, neotřelost přístupu, improvizaci, nadšení a nekonvenčnost. Tvořivost, předpokládáme, že i pohybová, se projevuje nalézáním takových řešení, která jsou nejen správná, ale současně také nová, nezvyklá, nečekaná (Průcha a kol., 2013). Při tvưrčí činnosti je nezastupitelná role inspirace, fantazie a intuice.

Námi vytvořený intervenční pohybový program hudebně-pohybové výchovy byl koncipován tak, aby nejen prostřednictvím rozmanitých pohybových činností byly stimulovány vybrané hudebně-pohybové schopnosti, ale aby také došlo k rozšíření počtu osvojených pohybových dovedností. Domníváme se, že signifikantní rozdíly mezi výsledky pretestu a posttestu společné pohybové tvořivosti byly ovlivněny výsledkem výběru jednotlivých cvičení a jejich členění do pěti skupin.

Zejména vnitřní motivace je hnacím prostř̌edkem tvůrčího jednání. Být tvořivý je ovlivněno i motivací vnější, například hudební předlohou či touhou prosadit se ve skupině. Zejména pro dívky pubertálního věku, kterými se výzkum zabývá, je sociální status a prestiž ve skupině důležitým aspektem úspěšnosti. Výsledky výzkumu žáků na základní škole (Bukvičková, 2012) poukazují na př́mý vliv mezi dostatkem zkušeností a uplatňováním improvizace a tvořivosti. Čím více zkušeností s improvizací a tvořivostí v tanečně pohybové výchově žáci mají, tím se stávají ve svých projevech sebevědomější.

Výsledky neprokázaly statistické zlepšení v testech rytmické percepce a v rytmické přizpůsobivosti. Pro uspokojivější efekt v následném výzkumu je třeba se zamyslet nad použitím i jiných testů s průkaznější reliabilitou a zabývat se věcnou významností výzkumu. Ve výzkumu Brtníkové, Novotné a Voříškové (2010) byl prokázán silný vliv věku na úroveň rytmických schopností. $\mathrm{K}$ tomuto poznatku je třeba přihlédnout při tvorbě hudebně-pohybových programů, a to zejména při volbě rytmické obtížnosti.

\section{ZÁVĚR}

Cílem předvýzkumu bylo vytvořit návrh intervenčního programu hudebně-pohybové výchovy a ověřit jeho vliv na vybrané hudebně-pohybové schopnosti skupiny žákyň ZŠ. Pracovní hypotézy byly stanoveny:

H0: Intervenční program nemá vliv na rozvoj vybraných hudebně-pohybových dovedností. H1: Intervenční program má vliv na rozvoj vybraných hudebnè-pohybových dovedností.

Na základě získaných výsledků a diskuze je možno odpovědět, že pro daný výzkumný soubor platí, že v př́ípadě hodnocení úrovně společné pohybové tvořivosti a dynamické rovnováhy měl aplikovaný intervenční program rozvíjející vliv. Na úroveň hodnocení rytmické percepce a rytmické přizpůsobivosti intervenční pohybový program vliv neměl.

Pro získání průkaznějších výsledků bude nutno provést experimentální studii s větší skupinou respondentů, s obměnou vyučujících a s porovnáním s kontrolní skupinou. Pro korektní výsledky bude nutno rozššřit měření o další standardizované metody testování hudebně-pohybových schopností. 
V rámci tvorby intervenčního programu bude potřeba se zaměřit více na aktivity pro rozvoj rytmické percepce a rytmické přizpůsobivosti. Pro úspěšné uplatnění a pochopení programu bude nutno rozšíriit znalosti žákyñ v oblasti teorie základních principů hudební rytmiky a jejího následného propojení do pohybové praxe. Předpokládáme, že výzkum vybraných aspektů v oblasti výuky hudebně-pohybové výchovy přispěje k získání dalších poznatků, které podpoří tvorbu a implementaci hudebně-pohybových programů podněcujících kreativitu do hodin školní tělesné výchovy.

\section{Literatura}

BATTISTI, J., \& HAIBACH, P. (2011). Progression Through Movement: Teaching Dance to Elementary Students. Journal of Physical Education, Recreation \& Dance, 82 (8), 14-16.

BRTNÍKOVÁ, M. (2008). Modernizace hudebně-pohybové výchovy. (Disertační práce). Praha: UK FTVS.

BRTNÍKOVÁ, M., NOVOTNÁ, V., \& VOŘǏ́̌KOVÁ, M. (2010). Ověření účinnosti nového hudebně-pohybového programu pro střední školy. Studia sportiva, 4 (2), 49-58.

BUKVIČKOVÁ, J. (2012). Improvizace a tvořivost v taneční a pohybové výchově na 1. stupni ZŠ. (Disertační práce) Praha: Univerzita Karlova v Praze.

FRÖMEL, K., STRATTON, G., VASENDOVA J., PANGRAZI, R. P. (2002). Dance as a Fitness Activity. The Impact of Teaching Style and Dance Form. Journal od Physical Education, Recreation and Dance, 73 (5), 26-30.

HONKOVÁ, K. (2011). Diagnostika koordinačních schopností ve sportovním tanci. (Diplomová práce). Brno: Masarykova Univerzita.

CHRÁSKA, M. (2016). Metody pedagogického výzkumu. Praha: Grada Publishing

CHRUDIMSKÝ, J., NOVOTNÁ, V. (2009). Gymnastické aktivity na základních školách. (62-70). In Pohybové aktivity v biosociálním kontextu. Ed. Čechovská, I., Tůma, M. Praha: Karolinum. ISBN 978-80-246-1553-0.

MĚKOTA, K., NOVOSAD, J. (2005). Motorické schopnosti. Olomouc: Univerzita Palackého.

MILLAR, V. (2011). Dance in Secondary Education: A Creative and Cultural Experience. Active \& Healthy Magazine, 18 (2), $15-18$.

NANU, L. (2010). Dance and music in physical education lesson for students. Dunarea de Jos, 53-55.

POKORNÝ, J. (1996). Tvořivé myšlení. Brno: Akademické nakladatelství CERM.

POKORNÁ, J., JANSA, P. (2012). Učitelé tělesné výchovy a realizace školních vzdělávacích programů na základních školách. Studia Kinanthropologica, 13 (3), 280-287. ISSN 1213-2101.

SIGMUND, E., FRÖMEL, K., CHMELÍK, F., LOKVENCOVÁ, P., \& GROFFIK, D. (2009). Oblíbený obsah avyučovacích jednotek tělesné výchovy - pozitivně hodnocený prostředek vyššího tělesného zatížení děvčat. Tělesná kultura, 32 (2), 45-63.

VÝZKUMNÝ ÚSTAV PEDAGOGICKÝ. (2013). Rámcový vzdělávací program základního vzdělávání. Praha.

\section{Elektronické zdroje}

PASTOROVÁ, M. (2010). Taneční a pohybová výchova - metodická podpora. Metodický portál: Články [online]. [cit. 2014-0601]. Dostupné z WWW:<http://clanky.rvp.cz/clanek/c/ZVHB/8017/TANECNI-A-POHYBOVA-VYCHOVA---METODICKAPODPORA.html>.

MAŇÁK, J. (2011). Aktivizující výukové metody. Metodický portál: Články [online]. 23. 11. 2011, [cit. 2017-01-11]. Dostupný z WWW: <http://clanky.rvp.cz/clanek/c/Z/14483/AKTIVIZUJICI-VYUKOVE-METODY.html>. ISSN 1802-4785

\section{Kontakt na autory:}

Mgr. Kateřina Doležalová, ka.ce.nka@seznam.cz, tel. +420 724825515

doc. PhDr. Viléma Novotná, vnovotna@ftvs.cuni.cz, tel.+420 220172076

Fakulta tělesné výchovy a sportu Univerzity Karlovy

José Martího 269/31

16252 Praha 6-Veleslavín

Česká republika 